\title{
ARTIFICIAL NEURAL NETWORK APPROACH TO PREDICT LMS ACCEPTANCE OF VOCATIONAL SCHOOL STUDENTS
}

\author{
Dr. Umut Birkan OZKAN \\ ORCID: 0000-0001-8978-3213 \\ Army NCO Vocational HE School \\ National Defence University \\ Balikesir, TURKEY
}

Dr. Harun CIGDEM

ORCID: 0000-0001-5958-5216

Army NCO Vocational HE School

National Defence University

Balikesir, TURKEY

Dr. Tolga ERDOGAN

ORCID: 0000-0002-1921-5517

Faculty of Education

TED University

Ankara, TURKEY

Received: 20/06/2019 Accepted: 10/02/2020

\begin{abstract}
The contribution of e-learning technologies, especially LMS which has become an important component of e-learning, is significantly increasing in higher education. It is critical to understand the factors that affect the behavioral intention of students towards LMS use. The aim of this study is to explore predictors of students' acceptance of Course Portal at a postsecondary vocational school level. We utilised a framework suggested by Sezer and Yilmaz (2019) for understanding students' acceptance of LMS. This framework obtains the main constructs in UTAUT: namely, performance expectancy, effort expectancy, social influence and facilitating conditions. More external variables, associate degree programs, high school type, academic grade point average were also adopted. Accordingly, 387 students were answered the questionnaire for investigating behavioral intention. Artificial neural network analysis (ANN) was used to predict students' acceptance of LMS use according to variables associated with their use of LMS technology. ANN analyses in the present study revealed that performance expectancy, effort expectancy, social influence and facilitating conditions are important predictors of students' behavioral intention to use LMS. Nevertheless, performance expectancy was found to be the most influencing predictor of LMS use. The analyses of this research provides evidence on the utilization of ANN to predict the determining factors of LMS acceptance.
\end{abstract}

Keywords: Artificial neural networks, LMS acceptance, UTAUT, MOODLE, social influence, vocational school

\section{INTRODUCTION}

With the rapid advancement in information and communication technologies and the result of investments in technological infrastructures at schools, electronic learning (e-learning) has been an important component of teaching and learning processes at every level from primary to higher and post-graduate education. Like in all educational institutions in developing countries, various institutions in Turkey have invested vastly 
on e-learning to support the quality of teaching and learning processes. Having been considered as one of the e-learning technologies, the learning management system (LMS) has been in use in various state and private universities to support either face-to-face or online instruction. LMS is one of the ever-developing information technologies instruments that facilitates e-learning and enables instruction with no time and space restraints. Specifically with the onset of LMS, e-learning has turned into an important method enhancing the use of new instructional practices that have been not carried out in traditional classroom settings (Cigdem, 2015).

With the utilization of technology, especially distance instructional technologies, in the education process, all stages from planning to classroom management and assessment were facilitated (Masud, 2016). LMSs are those technologies that enable presentation of instructional content in an orderly and various ways to students with no time and space restraints. As evident from its name, LMS is a management tool that can be used to manage instructional materials, observe the students and teachers and customize the teaching and learning processes. In other words, LMS is a web-based software designed to manage the learning activities. Today, some of the LMSs used by institutions are open source (e.g. Sakai, MOODLE-Modular Object-Oriented Dynamic Learning Environment, Dokeos, Drupal), while others are commercial (e.g. eFront, Blackboard, Brightspace). The institutions' purpose behind the use of LMS is to ease the learning activities and have them performed in a more systematic and planned way. It has been established that LMSs encourage a constructive approach to knowledge acquisition and support active learning (Emelyanova \& Voronina, 2014).

Among their many functions, LMSs are used to share instructional materials, plan debates, manage classrooms, assign homework and tasks, record the exams, receive feedback, organize learning materials, keep systems records of both students and teachers, and compose reports. LMSs offer both students and instructors various tools to improve the learning process and management (Stantchev et al., 2014). Together with these advantages, LMSs have a great potential for instructional utilization. Literature reveals that the utilization of LMSs in higher education has increased student motivation and attention, provided more flexible learning environments, and enabled better management of the teaching and learning time (Corbeil \& Valdes-Corbeil, 2007; Findik-Coskuncay \& Ozkan, 2013; Jacob \& Issac, 2008). While educational institutions spend a lot of money and effort to improve LMSs (Cigdem, 2015) and there is an increasing trend in the use of LMSs to facilitate the instructional activities, many higher education institutions that offer e-learning programs are facing difficulties in their course delivery (Legris, Ingham \& Collerette, 2003; Park, 2009).

As in other technologies, in terms of factors like usability, efficiency and suitability, LMSs need to be wellreceived by their potential users, the students and the instructors. If students make no use of LMSs, there is no profit in the investments (Pituch \& Lee, 2006). The precondition for better utilization of these technologies in educational settings is to get students ready for LMS use and create positive attitude, belief and intention towards their use, in other words, have students accept this technology (Davis, Bagozzi, \& Warshaw, 1989; Findik Coskuncay \& Ozkan, 2013; Sezer \& Yilmaz, 2019). For this particular purpose, if successful use of LMS is intended, it is important to understand students' intentions and the factors influencing their actual use. The acceptance of LMS technology has gained importance since internet infrastructure has developed in recent years and Web 2.0 technologies have become so popular that they compelled higher education institutions to take part in and manage such settings. In this respect; technology acceptance, which entails attitude, belief and intention towards technology use is an important factor. The model most widely used to investigate users' acceptance of different technologies is the Technology Acceptance Model (henceforth TAM) developed by Davis in 1989 (Davis \& Venkatesh, 1996). Technology acceptance has a construct that comprises cognitive and psychological components towards technology use (Venkatesh, Morris, Davis, \& Davis 2003). This construct aims to explain individuals acceptance of a certain technology and the factors behind their acceptance. Studies on LMS have examined technology acceptance at university level by utilizing varying technology acceptance models. TAM measures technology use intention under three components: perceived usefulness, perceived ease of use and behavioral intention.

Many researchers have criticized TAM for its limitations and tried to improve its explanatory power by adding various factors. Venkatesh et al. (2003) discussed the inadequacy of a single model to explain technology use and advocated multi-dimensional examination, hence developed the Unified theory of Acceptance and Use of Technology (UTAUT) model. According to Chen (2011) and Sumak, Polancic and Hericko (2010), 
UTAUT with its fundamental and sound model of new information technology acceptance can explain LMS acceptance and use. By incorporating similar components in eight different models, UTAUT includes four basic elements that determine an individual's aim of use: performance expectancy, effort expectancy, facilitating conditions and social influence (Venkatesh et al., 2003). The fundamental elements of UTAUT are briefly summarized below.

Performance expectancy (PE) is the belief that performance increases with the use of technology (Venkatesh et al., 2003). Several past studies (Raman \& Don, 2013; Venkatesh et al.,2003) found significant influence of PE on acceptance of LMS. Sumak et al. (2010) reported direct influence of PE on the intention to use LMS developed with Moodle. Another result found in the same study is that students' positive opinions about the benefits LMS may have on instructional practices affect their intention to use LMS.

Effort expectancy (EE) represents the belief that technology use will be easy and shows the effort expected to be spent by students on LMS (Venkatesh et al., 2003). Raman and Don (2013) highlighted the significant positive influence of effort expectancy on pre-school teachers' LMS acceptance. They also pinpointed that students' perceptions that LMS use doesn't necessitate effort influences their positive intentions on LMS use. Social influence (SI) reflects the influence of beliefs of others (peers, instructors and friends) on an individual's intentions or behavioral use (Venkatesh et al., 2003). It also projects that individuals' intentions or behavioral use may be influenced by other people's beliefs on the necessity of technology use and their beliefs on the utilization of e-learning. In their research, Raman et al. (2014) and Marchewka, Liu and Kostiwa (2007) found significant relationship between social influence and intention of LMS use. With the study at hand, the authors think that students' intention of LMS use may be influenced by their friends' or instructors' beliefs about LMS.

Facilitating conditions (FC) implies the existence of various elements that support technology use and focuses on the necessity of technical and institutional elements including instruction, support and infrastructure needed for e-learning (Venkatesh et al., 2003). Since this influences LMS use in some instances, students may need technical and/or instructional support.

Thus far, several research studies have examined LMS use and/or acceptance with those elements of UTAUT in mind. In their study using UTAUT as a model, Maina and Nzuki (2015) investigated the influence of performance expectancy, social influence, effort expectancy and facilitating conditions on LMS acceptance in higher education institutions in Kenya. The results confirmed that performance expectancy, infrastructure development, institutional policies, instructional support provided to users, ease of use and leadership had an influence on acceptance of LMS at higher education institutions.

In a study conducted by Raman et al. (2014), performance expectancy, facilitating conditions and social influence were found to have a significant influence on LMS, developed with Moodle.

Lwoga and Komba (2014) examined the factors influencing student LMS use. The results showed that, while actual use was determined by students' self-efficacy, the intention to use web-based learning system could be predicted by performance expectancy, social influence, self-efficacy and actual use. Additionally, LMS use was found to fail because of infrastructure barriers, limited skills, and the unfriendly nature of LMS, the inadequacy of managerial and technical support, lack of awareness, lack of time for e-content preparation, the e-learning system itself and resistance to change.

Taken together, LMS acceptance is deemed important for e-learning environments. With lack of related research in Turkey and in overall the need for further research to contribute to the understanding of the topic, the study at hand endeavors to examine the factors influencing students' acceptance of a Course Portal, a specific LMS developed by the utilization of Moodle to support the face-to-face instruction in a vocational school that accepts blended teaching methodology. 


\section{METHOD}

In this study, Artificial Neural Network (ANN) modelling was used to investigate the important factors of the acceptance of LMS use among vocational school students.

\section{Participants}

Convenient sampling method was used since the researchers worked at the vocational college where the participants were studying. The participants comprised 387 students having blended learning experience using Course Portal during the spring semester of 2018-2019 academic year. All participants were male living on the college premises. Some participants were studying Business Administration $(n=85)$ while the rest were from technical programs $(n=302)$. With regard to high school graduation, majority of them were vocational high schools graduates $(\mathrm{n}=246)$ and the others were graduates from state public schools $(\mathrm{n}=141) .38 .2 \%$ of the students had an academic GPA ranging between 2.00-2.99 and $61.5 \%$ of the students had GPAs between 3.00-4.00. Only one student had a GPA below 2.00 .

\section{Course Portal}

In order to support the face-to-face instruction at the vocational school, an LMS called "Course Portal" was developed by the use of MOODLE version 3.6. After class hours, students spent time at the Course Portal, loaded on computers in the computer labs. Since internet access was quite limited at school, instructors tried their best to keep the Course Portal content rich and updated. Teachers shared their lectures, presentations, sample projects, learning activities and videos related to their courses on the Course Portal, which could be accessed via an intranet system. Students also had the opportunity to login the system to take exams and upload their homework. Despite all those efforts on the part of instructors and the technical staff, students were not eager to use the Course Portal as it was desired. Hence, the authors of the study at hand decided to investigate the factors behind that reluctance. One of the screenshot examples of the Course Portal can be seen in Figure 1.

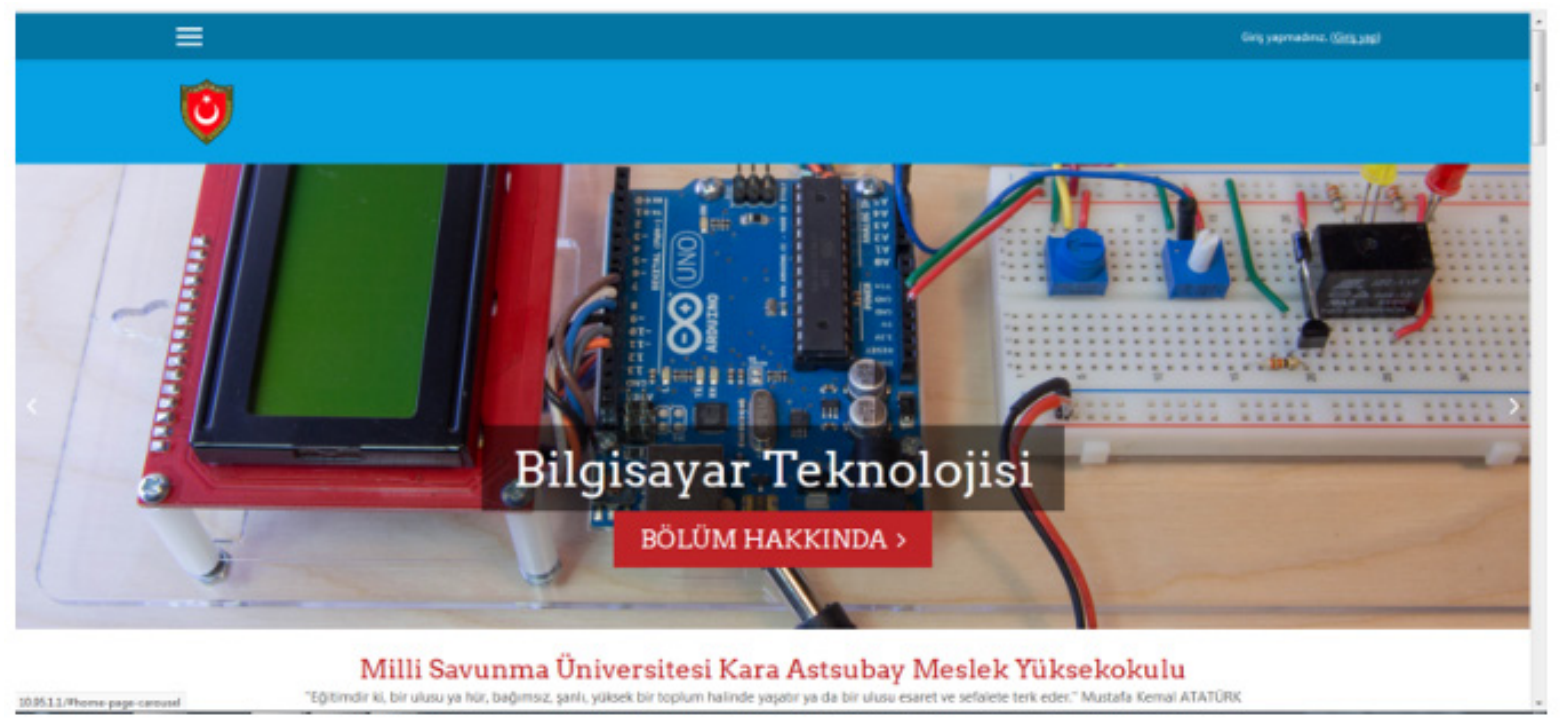

Figure 1. A screenshot of Course Portal

\section{Data Collection and Analysis}

"Learning management system acceptance scale (LMSAS)" (Sezer \& Y1lmaz, 2019) was used as the data collection instrument. LMSAS has four dimensions of performance expectancy, effort expectancy, facilitating conditions and social influence. The reliability was calculated using Cronbach's alpha $(\alpha)$. The $\alpha$ coefficient for the whole scale is .926 and coefficients for the four dimensions are given in Table 1. Having all coefficient values above 0.70 confirms the reliability of all subscales under consideration (Hair et al. 2010). 
Table 1. Cronbach's Alpha ( $\alpha$ ) Coefficients for All Subscales of LMSAS

\begin{tabular}{lll}
\hline Subscale & Total Items & (a) \\
\hline Performance expectancy (PE) & 8 & .934 \\
Effort expectancy (EE) & 5 & .785 \\
Facilitating conditions (FC) & 5 & .785 \\
Social influence (SI) & 3 & .838 \\
\hline
\end{tabular}

Students completed the scales on LMS. Additionally, students were required to enclose the program they were enrolling together with the type of school they graduated from and their current GPA scores. Artificial Neural Network (ANN) was utilized in data analysis.

Having been inspired by the human brain neural network, ANN is considered a mathematical model that stands for a substantially parallel and distributed processing system (Haykin, 2004; Greenwood, 1991; Pektas, 2013). In biological systems, learning incorporates modifications to the synaptic connections occuring between the neurones. The neural network approach was initially introduced to act like the human brain in solving problems. The novelty of this approach lies in its way of processing information (Greenwood, 1991). An ANN model comprises massive numbers of processing elements (neurones) that are interconnected and work together to solve sophisticated problems (Haykin, 2004). Among the three models of computer-based learning, namely supervised learning, unsupervised learning and reinforcement learning, an ANN model can be identified as supervised learning, since learning occurs depending on pre-existing examples known as training data. An ANN can be constructed for pattern recognition, data classification, and/or training and learning treatments.

As presented in Figure 2, an ANN model is composed of three layers of input, hidden and output. The hidden nodes is the layer where the inputs of $x_{1}, x_{2}, \ldots, x_{n}$ are processed and the output $y_{k}$ is released.

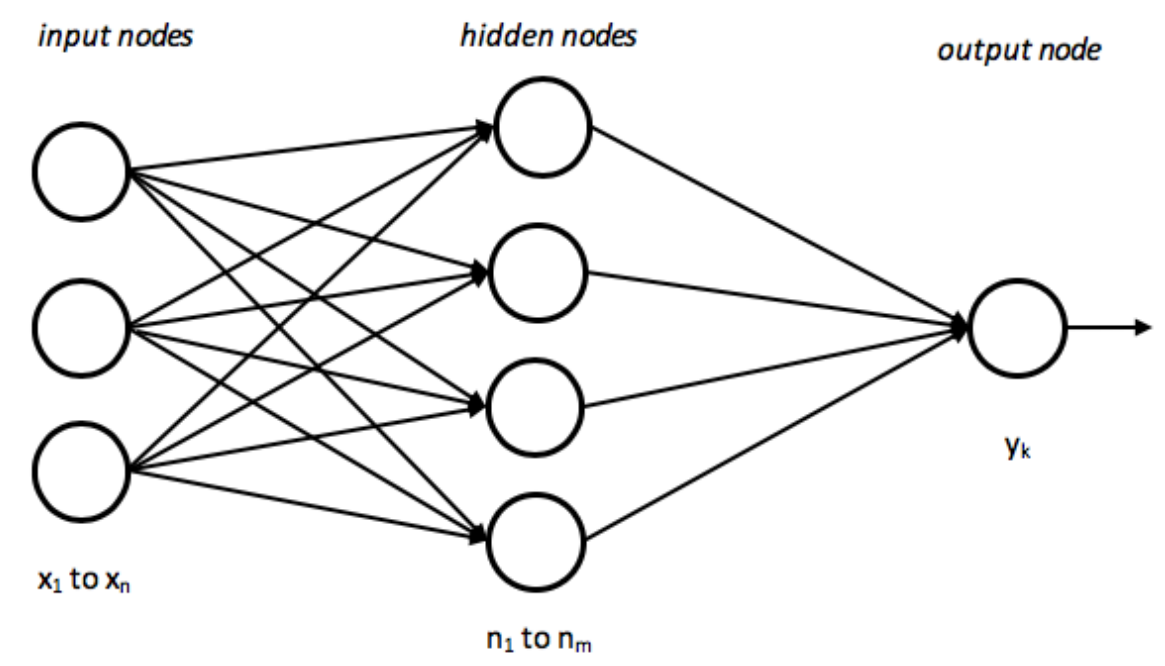

Figure 2. Sample ANN model

Owing to its computational power and the ability to process various types of data, the ANN model is utilized in various fields of information systems such as e-learning (Scott \& Walczak, 2009; Shmueli \& Koppius, 2011; Simoncini et al., 2017). Considered as non-parametric based models, the ANN models suggest diverse advantages with no consideration for distribution of input data, but with a strength of capturing linear and nonlinear relationships. Conversely, parametric based models hold certain concerns about distirbution of given data (Hair et al., 2010).

During ANN analysis, students' acceptance of LMS (AC) was taken as the output variable, also called the output layer, which corresponds to dependent variable in statistics. The programs students were enrolling, the schools they graduated from and their academic GPAs, which were estimated to influence all variables, were included into the analysis as categorical variables or factors. The predictive variables are the four 
dimensions of LMSAS. All the variables in the model were undergone a transformation of "standardization". In the partition of data set, random cases were assigned in accordance with relative case number. The present data were classified as training data, testing data, and validation data. No specific method exists in the classification of data. According to Zhang et al. (1998), data are frequently classified as $80 \%$ training and $20 \%$ testing or $70 \%$ training and $30 \%$ testing. In this study, the rates were defined as $60 \%$ training data, $30 \%$ testing data and $10 \%$ validation data. IBM SPSS Statistic 22 pack was utilized during analyses, where the architecture of the ANN model was automatically designed. With the selection of automatic architecture, hyperbolic tangent function was identified as the interlayer activation function and identity function was selected for the output layer. In automatic architecture selection option, number of hidden layers is chosen as 1. Literature reveals frequent use of 3-layered network structures with one hidden layer (Han \& Wang, 2011; Hippert et al., 2001; Zhang et al., 1998). IN ANN analysis, online learning was preferred as the learning method. The existence of interdependence of analysis data was the rationale behind this selection.

In the present research, the ANN analysis results were compared with the results of cross-correlation analysis. Cross-correlation analysis yields the highest correlations by analysing the cross-correlation function between two variables in a data set. With cross-correlation alaysis, the cross-correlations between the forward and backward series of independent variables and the dependent variable were examined to identify the highsy meaningful relationships between the dependent variable and the independent variables (Albayrak, 2014). IBM SPSS Statistics 22 default value of 7 was accepted as the forward and backward maximum number of lags.

\section{FINDINGS}

This research aimed to analyze the importance levels of predictors effective on students' acceptance of LMS use. The Sum of Squares Error and Relative Error found for the training level were .121 and .001, while the values for the testing level were .078 and .002 . The Relative Error for the validation levels was .003 . The error calculations of IBM SPSS Statistic 22 was based on testing example. This section presents the findings obtained about the order of significance of independent variables influencing students' acceptance of LMS use. The run summary of data included to ANN analysis is presented in Table 2.

Table 2. ANN Data Run Summary

\begin{tabular}{lll}
\hline & $\mathrm{N}$ & $\%$ \\
\hline Training data & 243 & 62.8 \\
Testing data & 106 & 27.4 \\
Validation data & 38 & 9.8 \\
Valid data & 387 & 100 \\
Excluded data & 0 & \\
Total & 387 & \\
\hline
\end{tabular}

Table 2 shows that the whole data set was split into training $(62.8 \%, n=243)$, testing $(27.4 \%, n=106)$ and validation $(9.8 \%, \mathrm{n}=38)$. All data used were valid, no data were excluded. The structure of the established ANN model and the neural networks are presented in Figure 3. 


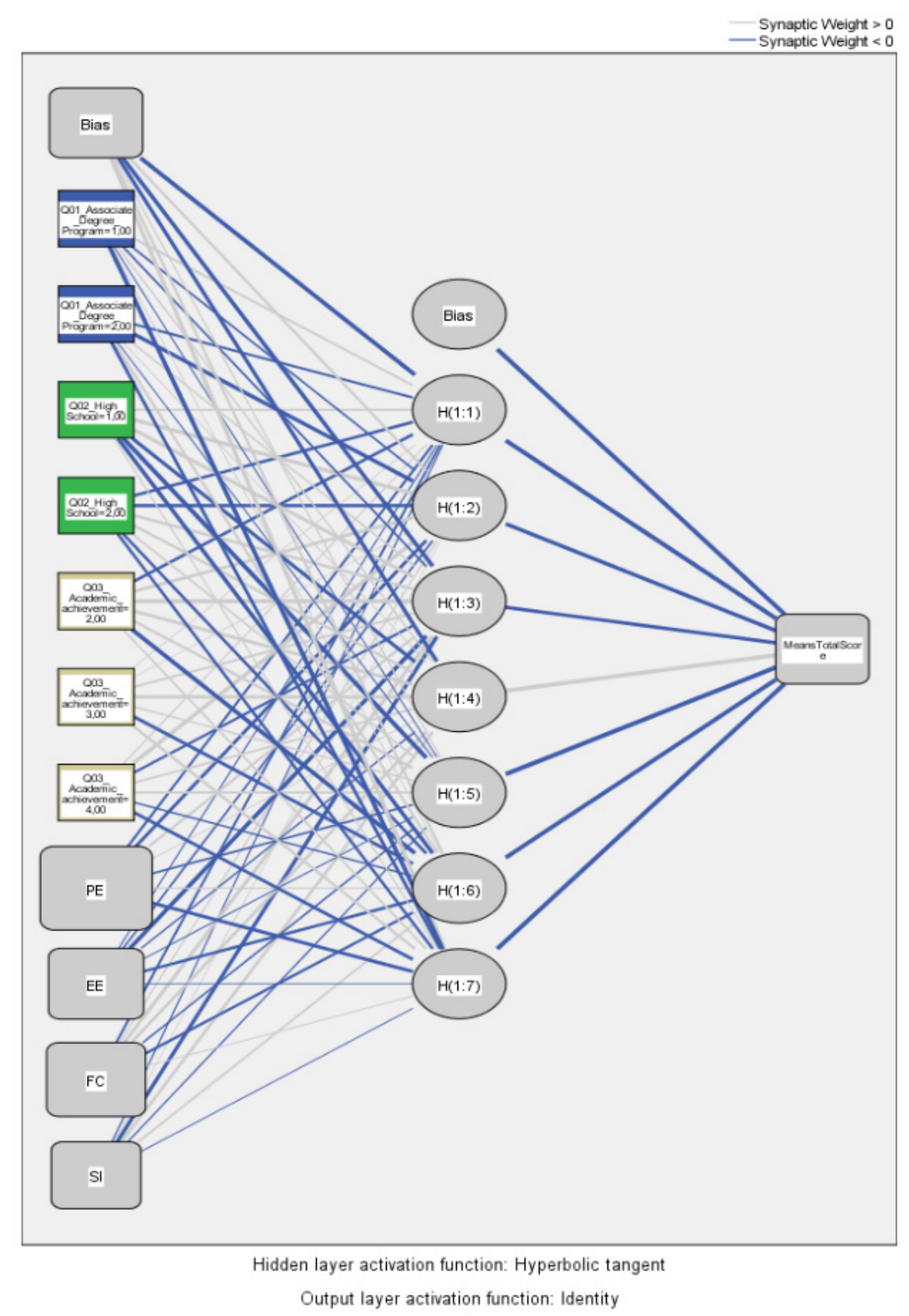

Figure 3. ANN model structure

The weights of independent variables in the artificial neural network can be seen in Figure 4. To determine the ratings of independent variables' importance, in accordance with the weights linking the artificial neural cells in the network, the ratings were defined in percentages and are presented in Table 3. 
Table 3. The Importance Ratings of Independent Variables Related to Students' Acceptance of LMS Use

\begin{tabular}{lll}
\hline Independent Variable & Importance & Normalized Importance \\
\hline Associate Degree Programs & .006 & $1.6 \%$ \\
High school type & .005 & $1.3 \%$ \\
Academic Grade Point Average & .011 & $2.9 \%$ \\
Performance expectancy & .378 & $100 \%$ \\
Effort expectancy & .206 & $54.4 \%$ \\
Facilitating conditions & .246 & $65.2 \%$ \\
Social influence & .149 & $39.3 \%$ \\
\hline
\end{tabular}

Figure 4 shows the graphical demonstration of importance ratings of independent variables.

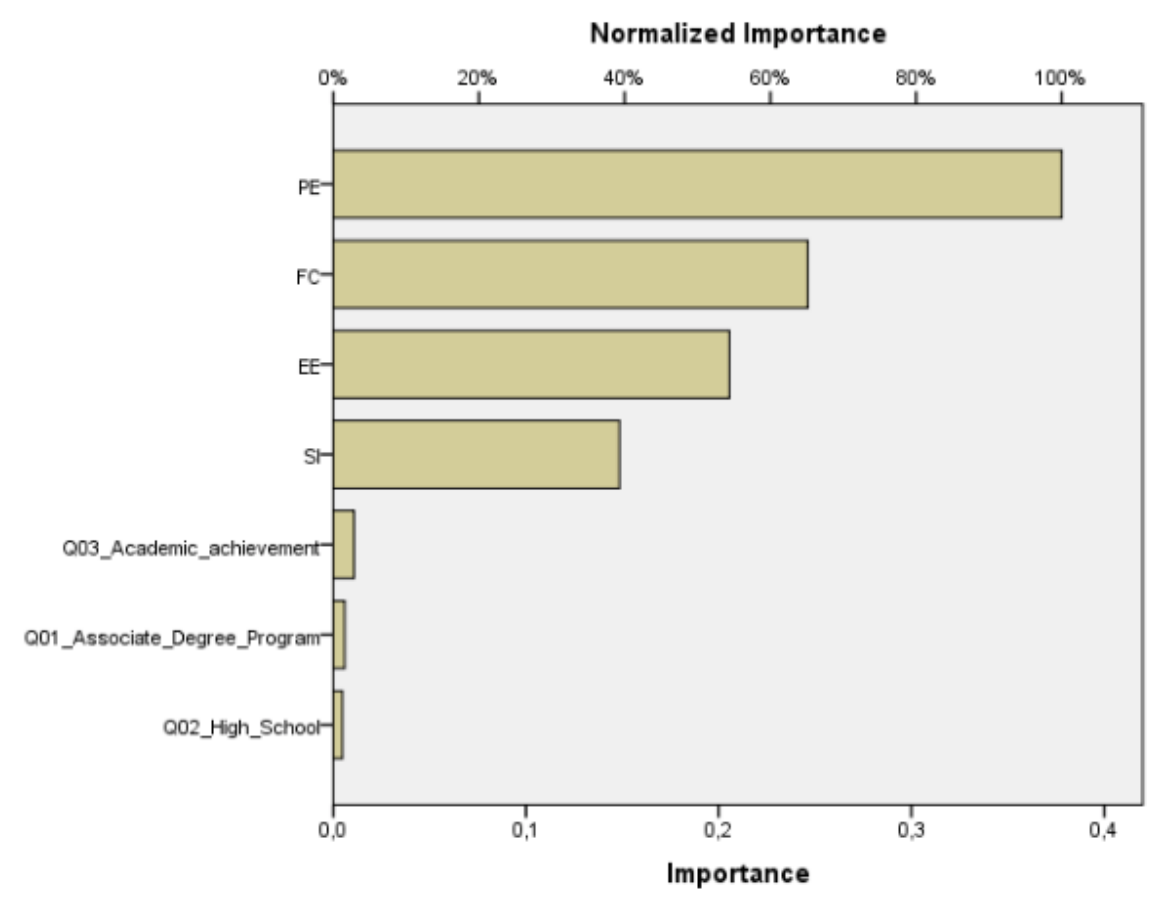

Figure 4. Importance Ratings of Independent Variables

Analysis of both Table 3 and Figure 4 reveals students' performance expectations as the most important independent variable in the ANN structured for students' acceptance of LMS use. This finding suggests more tendency towards LMS use after academic achievement is gained due to LMS use. The other variables following this independent variable are facilitating conditions (65.2\%), effort expectancy (54.4\%) and social influence of LMS use (39.3\%). Those variables having the least effect on students' acceptance of LMS use can be listed as academic grade point average (2.9\%), associate degree program (1.6\%) and the type of high school students graduated from (1.3\%). The basic reason behind this finding could be stated as students' free and equal access to both the internet and the LMS at school. Hence, these variables might not be a cause of anxiety when acceptance of LMS is considered.

ANN results were compared by cross-correlation analysis, which ensures the identification of the highest correlations among the variables. Table 4 below presents the cross-correlation analysis results between the acceptance of LMS and the four dimensions of LMSAS. 
Table 4. Cross-correlations Between LMS Acceptance and the Four Dimensions of LMSAS

\begin{tabular}{|c|c|c|c|c|c|c|c|c|c|c|c|}
\hline \multicolumn{3}{|c|}{$\begin{array}{l}\text { Performance expectancy } \\
\text { and LMS Acceptance }\end{array}$} & \multicolumn{3}{|c|}{$\begin{array}{l}\text { Facilitating conditions and } \\
\text { LMS Acceptance }\end{array}$} & \multicolumn{3}{|c|}{$\begin{array}{l}\text { Effort expectancy and LMS } \\
\text { Acceptance }\end{array}$} & \multicolumn{3}{|c|}{$\begin{array}{l}\text { Social influence and LMS } \\
\text { Acceptance }\end{array}$} \\
\hline Lag & $\begin{array}{l}\text { Cross } \\
\text { Correlation }\end{array}$ & $\begin{array}{l}\text { Std. } \\
\text { Error }^{\mathrm{a}}\end{array}$ & Lag & $\begin{array}{l}\text { Cross } \\
\text { Correlation }\end{array}$ & $\begin{array}{l}\text { Std. } \\
\text { Error }^{\mathrm{a}}\end{array}$ & Lag & $\begin{array}{l}\text { Cross } \\
\text { Correlation }\end{array}$ & $\begin{array}{l}\text { Std. } \\
\text { Error }^{\mathrm{a}}\end{array}$ & Lag & $\begin{array}{l}\text { Cross } \\
\text { Correlation }\end{array}$ & $\begin{array}{l}\text { Std. } \\
\text { Error }\end{array}$ \\
\hline $\begin{array}{l}-7 \\
\end{array}$ & .075 & .051 & -7 & .042 & .051 & -7 & .045 & .051 & -7 & -.005 & .051 \\
\hline-6 & .086 & .051 & -6 & -.009 & .051 & -6 & -.043 & .051 & -6 & .070 & .051 \\
\hline-5 & .015 & .051 & -5 & .043 & .051 & -5 & .008 & .051 & -5 & .044 & .051 \\
\hline-4 & -.018 & .051 & -4 & .011 & .051 & -4 & -.023 & .051 & -4 & -.127 & .051 \\
\hline-3 & .022 & .051 & -3 & .100 & .051 & -3 & .008 & .051 & -3 & -.021 & .051 \\
\hline-2 & .067 & .051 & -2 & .028 & .051 & -2 & -.026 & .051 & -2 & .079 & .051 \\
\hline-1 & .083 & .051 & -1 & .148 & .051 & -1 & .059 & .051 & -1 & .125 & .051 \\
\hline 0 & .890 & .051 & 0 & .774 & .051 & 0 & .835 & .051 & 0 & 669 & .051 \\
\hline 1 & .111 & .051 & 1 & .052 & .051 & 1 & .086 & .051 & 1 & .150 & .051 \\
\hline 2 & .020 & .051 & 2 & .065 & .051 & 2 & .052 & .051 & 2 & .041 & .051 \\
\hline 3 & .027 & .051 & 3 & .057 & .051 & 3 & .090 & .051 & 3 & -.068 & .051 \\
\hline 4 & -.052 & .051 & 4 & -.014 & .051 & 4 & -.050 & .051 & 4 & -.009 & .051 \\
\hline 5 & .025 & .051 & 5 & .054 & .051 & 5 & .011 & .051 & 5 & .010 & .051 \\
\hline 6 & .041 & .051 & 6 & .081 & .051 & 6 & -.010 & .051 & 6 & .018 & .051 \\
\hline 7 & .040 & .051 & 7 & .063 & .051 & 7 & .042 & .051 & 7 & .040 & .051 \\
\hline
\end{tabular}

The correlation values presented in Table 4 confirm the predictor of Performance Expectancy (.89) having the highest correlation with LMS acceptance. That variable is followed by Effort Expectancy (.835), Facilitating Conditions (.774) and Social Influence (.669). The ranking according to these values is parallel to the importance ranking in LMS analysis results. The cross-correlation analysis results between LMS Acceptance and student academic achievement as its predictor are shown in Table 5.

Table 5. Cross-correlations Between LMS Acceptance and Student Academic Achievement

Academic grade point: 1-1,99 and LMS Academic grade point: 2-2,99 and LMS Academic grade point: 3-4 and LMS Acceptance Acceptance Acceptance

\begin{tabular}{lllllllll}
\hline Lag & Cross Correlation & Std. Error & Lag & Cross Correlation & Std. Error & Lag & Cross Correlation & Std. Error $^{\mathrm{a}}$ \\
\hline-7 & .000 & .051 & -7 & -.136 & .051 & -7 & .136 & .051 \\
-6 & .000 & .051 & -6 & -.137 & .051 & -6 & .137 & .051 \\
-5 & .001 & .051 & -5 & -.145 & .051 & -5 & .145 & .051 \\
-4 & .001 & .051 & -4 & -.147 & .051 & -4 & .147 & .051 \\
-3 & .000 & .051 & -3 & -.152 & .051 & -3 & .151 & .051 \\
-2 & .000 & .051 & -2 & -.156 & .051 & -2 & .156 & .051 \\
-1 & .000 & .051 & -1 & -.153 & .051 & -1 & .152 & .051 \\
0 & -.085 & .051 & 0 & -.158 & .051 & 0 & .166 & .051 \\
1 & .088 & .051 & 1 & -.163 & .051 & 1 & .153 & .051 \\
2 & -.195 & .051 & 2 & -.135 & .051 & 2 & .155 & .051 \\
3 & .007 & .051 & 3 & -.146 & .051 & 3 & .145 & .051 \\
4 & -.012 & .051 & 4 & -.145 & .051 & 4 & .146 & .051 \\
5 & -.008 & .051 & 5 & -.144 & .051 & 5 & .145 & .051 \\
6 & -.063 & .051 & 6 & -.130 & .051 & 6 & .136 & .051 \\
7 & -.038 & .051 & 7 & -.125 & .051 & 7 & .129 & .051 \\
\hline
\end{tabular}


Correlations values presented in Table 5 conclude the existence of very low correlations between acceptance of LMS and Student academic achievement. Taking all three score intervals into account, the highest correlation value is .195. This finding supports the results of LMS analysis. The cross-correlations between students' acceptance of LMS and their associate degree programs and type of high schools they graduated from are presented in Table 6 .

Table 6. Cross-correlations Between LMS Acceptance and Students' Associate Degree Programs and Type of High Schools

\begin{tabular}{cccccccccccc}
\hline \multicolumn{2}{c}{$\begin{array}{c}\text { Business Administration and } \\
\text { LMS Acceptance }\end{array}$} & \multicolumn{3}{c}{$\begin{array}{c}\text { Technical Departments and } \\
\text { LMS Acceptance }\end{array}$} & \multicolumn{3}{c}{$\begin{array}{c}\text { General High School and } \\
\text { LMS Acceptance }\end{array}$} & \multicolumn{3}{c}{$\begin{array}{c}\text { Vocational High School and } \\
\text { LMS Acceptance }\end{array}$} \\
\hline Lag & $\begin{array}{c}\text { Cross } \\
\text { Correlation }\end{array}$ & $\begin{array}{c}\text { Std. } \\
\text { Errora }\end{array}$ & Lag & $\begin{array}{c}\text { Cross } \\
\text { Correlation }\end{array}$ & $\begin{array}{c}\text { Std. } \\
\text { Errora }\end{array}$ & Lag & $\begin{array}{c}\text { Cross } \\
\text { Correlation }\end{array}$ & $\begin{array}{c}\text { Std. } \\
\text { Errora }\end{array}$ & Lag & $\begin{array}{c}\text { Cross } \\
\text { Correlation }\end{array}$ & $\begin{array}{c}\text { Std. } \\
\text { Errora }\end{array}$ \\
\hline-7 &, 091 &, 051 & -7 &,- 091 &, 051 & -7 &, 062 &, 051 & -7 &,- 062 &, 051 \\
-6 &, 063 &, 051 & -6 &,- 063 &, 051 & -6 &,- 001 &, 051 & -6 &, 001 &, 051 \\
-5 &,- 009 &, 051 & -5 &, 009 &, 051 & -5 &, 045 &, 051 & -5 &,- 045 &, 051 \\
-4 &,- 017 &, 051 & -4 &, 017 &, 051 & -4 &,- 008 &, 051 & -4 &, 008 &, 051 \\
-3 &,- 007 &, 051 & -3 &, 007 &, 051 & -3 &,- 008 &, 051 & -3 &, 008 &, 051 \\
-2 &,- 007 &, 051 & -2 &, 007 &, 051 & -2 &,- 021 &, 051 & -2 &, 021 &, 051 \\
-1 &, 012 &, 051 & -1 &,- 012 &, 051 & -1 &, 033 &, 051 & -1 &,- 033 &, 051 \\
0 &,- 046 &, 051 & 0 &, 046 &, 051 & 0 &, 074 &, 051 & 0 &,- 074 &, 051 \\
1 &,- 035 &, 051 & 1 &, 035 &, 051 & 1 &,- 105 &, 051 & 1 &, 105 &, 051 \\
2 &,- 026 &, 051 & 2 &, 026 &, 051 & 2 &, 013 &, 051 & 2 &,- 013 &, 051 \\
3 &,- 044 &, 051 & 3 &, 044 &, 051 & 3 &,- 028 &, 051 & 3 &, 028 &, 051 \\
4 &,- 012 &, 051 & 4 &, 012 &, 051 & 4 &, 047 &, 051 & 4 &,- 047 &, 051 \\
5 &, 044 &, 051 & 5 &,- 044 &, 051 & 5 &, 015 &, 051 & 5 &,- 015 &, 051 \\
6 &, 007 &, 051 & 6 &,- 007 &, 051 & 6 &,- 082 &, 051 & 6 &, 082 &, 051 \\
7 &,- 019 &, 051 & 7 &, 019 &, 051 & 7 &, 000 &, 051 & 7 &, 000 &, 051 \\
\hline
\end{tabular}

As in the previous analysis, correlations values presented in Table 6 conclude the existence of very low correlations between students' acceptance of LMS and their associate degree programs and type of high schools they graduated from. This finding of having two predictive variables with the lowest importance could be considered as an evidence for the pertinence of the LMS analysis.

\section{DISCUSSION}

The contribution of e-learning technologies, especially LMS which has become an important component of e-learning, is significantly increasing in higher education. It is essential to understand the factors that affect the behavioral intention of students towards LMS use.

Artificial Neural Network Analyses in the present study revealed that performance expectancy, effort expectancy, social influence and facilitating conditions are important predictors of students' behavioral intention to use LMS. Nevertheless, performance expectancy was found to be the most influencing predictor of LMS acceptance. This could be explained as students' acceptance of LMS may increase when students realize its productive value. This finding is also consistent with the findings obtained by Raman and Don (2013) and Sumak et al. (2010), where performance expectancy was found to have direct effect on intention to use LMS. Thus, it might be a good practice on the part of instructors to furnish LMSs with rich content, which in turn might contribute to student performance in class.

This study at hand found that facilitating conditions is the second most influencing factor of acceptance of LMS. Preparing a manual for LMS use, having instructors explain LMS use in the first weeks of classes, offering students laboratories where they can have easy access to LMSs and extending support to those students having problems with LMS use could be counted as facilitating conditions.

Effort expectancy factor is the third important predictor of LMS acceptance among vocational school students. Similarly in their research, Raman and Don (2013) found significant effect of effort expectancy 
on pre-school teachers' acceptance of LMS use. Ease of use and/or learning might contribute to intention to use LMSs

Social influence is the fourth most influencing predictor of acceptance of LMS. This could be discoverable, because students' LMS use can increase depending on the support or encouragement they get from their peers or instructors or if students realize the value of LMS use, they may tend to use it more. This finding is consistent with the results of several other studies (Marchewka, Liu \& Kostiwa, 2007; Raman et al., 2014). Previous research found significant relationship between social influence and intention to use LMS. Without a doubt, a social influence develops when the instructors lead students to have more access to LMS or when the students discover themselves or observe from their friends the value of LMS use.

The results obtained are not in concordance with the results of the original UTAUT model and various other studies (Venkatesh et al., 2003), owing majorly to differences of context. It could be stated that students or users in developing countries, like in Turkey, would adopt more e-learning technologies such as LMS, if they had the knowledge and necessary resources which those developed countries already have.

On the contrary, the findings of the present study revealed that the type of high school students graduated from, their associate degree programs and academic achievements were not among the factors influencing students' acceptance of LMS use. Though, this could be adhered to the characteristics of the study group, it could also indicate that students used the LMSs equally no matter from which school they graduated from, what program they study or what level of achievement they have.

\section{CONCLUSION}

The research was conducted to identify students' acceptance of LMS at a vocational school and to find out to which extent variables such as high school graduation, degree program, academic achievement, performance expectancy, effort expectancy, social influence, and facilitating conditions predict that acceptance. This study is believed to contribute to the understanding of nature and degree of postsecondary vocational college students' acceptance of LMS. It is deemed essential to discuss such significant factors influencing the teaching approaches and it sounds important for investments on LMSs as well. Besides, since LMSs have been accepted by many higher education institutions, there is a need to see the factors that predict students' acceptance of LMS.

The findings in this study suggest that performance expectancy, facilitating conditions, effort expectancy, social influence predict students' acceptance of LMS. Another suggestion is that type of high school graduation, degree program, and academic achievement are not that influential on LMS acceptance.

In line with the results obtained, this research is considered to have some implications. Firstly, this research might support and extend the understanding of vocational school teachers in Turkey on the importance of having students' acceptance of LMS, so that they could successfully integrate them as part of their learning strategies. Students are believed to use LMS more after their expectations are met by the careful organization and improvement of courses by the teachers.

Internet is a giant door opening to vast amount of information, however students are often lost while doing a research and lose time. The LMSs developed by schools will help students have access to information they need more easily and quickly. To support students in their use of LMS, instructors could ensure them that the uploaded documents and videos etc. are useful for them. There won't be much time lost, since the instructors develop, filter and upload the necessary materials on the LMSs. Better gains could be achieved when students realize that they can have immediate answers to their problems at hand, when the LMSs is easy to learn, when the materials uploaded are up-to-date and essential to learning, when students are motivated to use the LMSs and when they see from others the benefits of LMS use. Thus, students rate of LMS use would increase owing to the instructors' integratation of LMS into curricula and encouragement of students.

Secondly, ANN analysis used in the research at hand provided additional findings regarding the relationships between acceptance of LMS and other independent predictors. So, ANN could be comfortably used in other technology acceptance studies and contribute to the understanding of factors influencing students or learners acceptance. 


\section{Limitations and Suggestions for Future Research}

This present study has several limitations. First, the findings of the artificial neural network as a predictive model could be supported with other statistical models. Second, this study was carried on data derived from a Turkish vocational school, where MOODLE was used as an LMS. For generalization of the findings of the present research, subsequent studies may be required in other educational institutions in other countries and at different levels using various LMSs. Third, future studies can focus on students' permanent use of LMS, which was not handled in this research. Finally, further research focusing on prediction of instructors' behavioral intention to use LMSs could contribute to the understanding of technology use in classes.

\section{BIODATA and CONTACT ADDRESSES of AUTHORS}

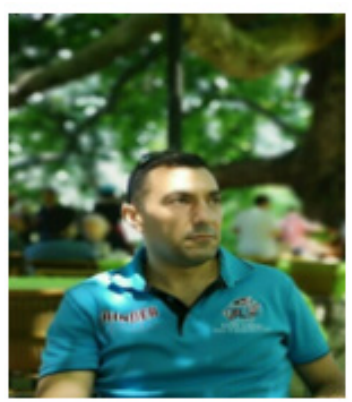

Dr. Umut Birkan OZKAN is head of Educational Sciences Department at National Defence University Army NCO Vocational HE School, Balıkesir, TURKEY. He has a teaching experience of 21 years at various levels, from secondary to higher education. Dr. Ozkan gained his Ph.D. in Curriculum and Instruction in May, 2016. His academic interest areas are curriculum studies, teacher education, instructional design, academic achievement, large scale assessments and instructional technologies. He has 3 books, over 10 journal articles published in international and national indexes, 2 international book chapters and he has presented several papers at international meetings.

Umut Birkan OZKAN

National Defence University, Army NCO Vocational HE School, Department of Educational Sciences Address: National Defence University Army NCO Vocational HE School, 10100, Balıkesir, TURKEY Phone: +902662212350

E-mail: umutbirkanozkan@gmail.com

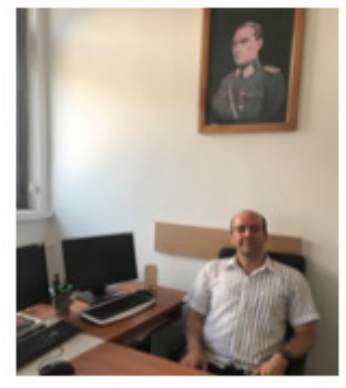

Dr. Harun CIGDEM is an Associate Professor at Computer Technologies Department, at National Defence University Army NCO Vocational HE School, Balıkesir, TURKEY. He holds a bachelor's degree in Computer Education and Instructional Technologies and a master's degree in Educational Sciences from Bursa Uludag University. He received his $\mathrm{PhD}$ in Computer Education and Instructional Technologies from Anadolu University in 2012. He is the administrator of Course Portal (LMS) of National Defence University Army NCO Vocational HE School. He teaches operating systems, computer networks, and system and network administration courses in the college. His research interests involve instructional design, e-learning, e-assessment and self-regulation.

\section{Harun CIGDEM}

National Defence University, Army NCO Vocational HE School, Computer Technologies Address: National Defence University Army NCO Vocational HE School, 10100, Balıkesir, TURKEY Phone: +902662212350

E-mail: hcigdem@gmail.com 


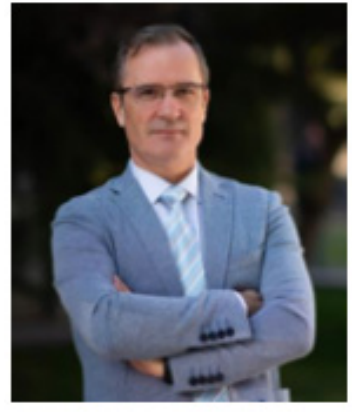

Dr. Tolga ERDOGAN is an Associate Professor of Educational Sciences at TED University, Faculty of Education. He has a teaching experience of 24 years at various levels, from secondary to higher education. Dr. Erdogan gained his Ph.D. in Curriculum and Instruction in April, 2012. His academic interest areas are constructivist teaching and learning, self-regulation, metacognition, learner/ learning friendly environments, testing and evaluation, and instructional technologies. He has over 12 journal articles published in international and national indexes, 2 national and international book chapters and he has presented several papers at international meetings.

\section{Tolga ERDOGAN}

TED University, Faculty of Education, Department of Educational Sciences

Address: TED University, Faculty of Education, 06420, Ankara, Turkey

Phone: +903125850371

E-mail: tolga.erdogan@tedu.edu.tr

\section{REFERENCES}

Albayrak, A. S. (2014). Otokorelasyon durumunda en kucuk kareler tekniginin alternatifi otoregresyon teknikleri ve bir uygulama. Suleyman Demirel Universitesi Iktisadi ve Idari Bilimler Fakultesi Dergisi, 19(1), 1-20.

Chen, J.L., (2011). The effects of education compatibility and technological expectancy on e-learning acceptance. Computers and Education, 57, 1501-1511.

Cigdem, H. (2015). How does self-regulation affect computer-programming achievement in a blended context? Contemporary Educational Technology, 6(1), 19-37.

Corbeil, J. R., \& Valdes-Corbeil, M. E. (2007). Are you ready for mobile learning? Educause Quarterly, 2, 51-58. Retrieved from http://er.educause.edu/ /media/files/article-downloads/eqm0726.pdf

Davis, F. D. (1989). Perceived usefulness, perceived ease of use, and user acceptance of information technology. MIS Quarterly, 13, 983-1003.

Davis, F. D., Bagozzi, R. P., \& Warshaw, P. R. (1989). User acceptance of computer technology: A comparison of two theoretical models. Management Science, 35(8), 982-1003.

Davis, F. D., \& Venkatesh, V. (1996). A critical assessment of potential measurement biases in the technology acceptance model: Three experiments. International Journal of Human-Computer Studies, 45(1), $19-45$.

Emelyanova, N., \& Voronina, E. (2014). Introducing a learning management system at a Russian university: Students' and teachers' perceptions. The International Review of Research in Open and Distributed Learning, 15(1), 273-289.

Findik-Coskuncay, D., \& Ozkan, S. (2013). A model for instructors' adoption of learning management systems: Empirical validation in higher education context. TOJET: The Turkish Online Journal of Educational Technology, 12(2), 13-25.

Greenwood, D. (1991). An overview of neural networks. Systems Research and Behavioral Science, 36, 1-33.

Hair, J. F., Black,W. C., Babin, B. J., Anderson, R. E., \& Tatham, R. L. (2010). Multivariate data analysis (7th ed.). Upper Saddle River: Prentice-Hall.

Han, Y., \& Wang, B. (2011). Investigation of listed companies credit risk assessment based on different learning schemes of BP neural network. International Journal of Business and Management, 6(2), 204-207. 
Haykin, S. (2004). Neural Networks: A Comprehensive Foundation. Pearson Education.

Hippert, H.S., Pedreira, C.E., \& Souza, R.C..(2001). Neural networks for short-term load forecasting: a review and evaluation. IEEE Transactions on Power Systems, 16(1), 44-55.

Jacob, S. M., \& Issac, B. (2008, March). The mobile devices and its mobile learning usage analysis. In Proceedings of the International Multi Conference of Engineers and Computer Scientists-IMECS (pp. $19-21)$.

Legris, P., Ingham, J., \& Collerette, P. (2003). Why do people use information technology? A critical review of the technology acceptance model. Information \& Management, 40, 191-204.

Lwoga, E.,\&Komba (2014). Understanding university students' behavioural continued intentions to use e-learning in Tanzania. Proceedings and Report of the 7th UbuntuNet Alliance Annual Conference, $167-188$

Maina, M. K. \& Nzuki, D .M. (2015). Adoption Determinants of E-learning Management System in Institutions of Higher Learning in Kenya: A Case of Selected Universities in Nairobi Metropolitan. International Journal of Business and Social Science, 6 (2).

Marchewka, J. T., Liu, C., \& Kostiwa, K. (2007). An Application of the UTAUT Model. Communications of the IIMA, 94(7), 93-104.

Masud, M. M. (2016). Collaborative e-learning systems using semantic data interoperability. Computers in Human Behavior, 61, 127-135.

Park, S. Y. (2009). An analysis of the technology acceptance model in understanding university students' behavioral intention to use e-Learning. Educational Technology \& Society, 12(3), 150-162.

Pektas, A.O. (2013). Data Mining with SPSS (SPSS ile Veri Madenciligi). Istanbul: Dikeyeksen Yayıncilık.

Pituch K.A. \& Lee Y.k. (2006) The influence of system characteristics on e-learning use. Computers \& Education, 47, 222-244.

Raman A. \& Don, Y. (2013) Preservice teachers' acceptance of learning management software: An application of the UTAUT2 Model. International Education Studies, 6(7), 157-164.

Raman, A., Don, Y., Khalid, R., \& Rizuan, M. (2014). Usage of learning management system (Moodle) among postgraduate students: UTAUT Model. Asian Social Science 10(14), 186-192.

Scott, J. E. \& Walczak, S. (2009). Cognitive engagement with a multimedia ERP training tool: Assessing computer self-efficacy and technology acceptance. Information \& Management, 46, 221-232.

Sezer, B., \& Yilmaz, R. (2019). Learning management system acceptance scale (LMSAS): A validity and reliability study. Australasian Journal of Educational Technology, 35(3), 15-30.

Shmueli, G. \& Koppius, O. R. (2011). Predictive analytics in information systems research. Mis Quarterly, 553-572.

Simoncini, A., Tagliaferri, V., Trovalusci, F. \& Ucciardello, N. (2017). Neural networks approach for IRheating and deformation of ABS in thermoforming. International Journal of Computer Applications in Technology, 56, 114-120.

Stantchev, V., Colomo-Palacios, R., Soto-Acosta, P., \& Misra, S. (2014). Learning management systems and cloud file hosting services: A study on students' acceptance. Computers in Human Behavior, 31, 612-619.

Sumak B, Polancic G and Hericko M (2010) An empirical study of virtual learning environment adoption using UTAUT. In: Second International Conference on Mobile, Hybrid, and On-Line Learning ELML, 10-16 February 2010. Saint Maarten: IEEE, 17-22.

Venkatesh, V., Morris, M. G., Davis, G. B., \& Davis, F. D. (2003). User acceptance of information technology: Toward a unified view. MIS Quarterly, 27(3), 425-478.

Zhang, G., Patuwo, B. E., \& Hu, M. Y. (1998). Forecasting with artificial neural networks: The state of the art. International journal of forecasting, 14(1), 35-62. 